\title{
An Analysis of the Jurisdiction of the National Industrial Court of Nigeria as a Court of First and Last Resort in Civil Matters
}

\author{
Dr Etefia E. Ekanem ${ }^{1} *$ and Bassey J. Ekanem ${ }^{2}$ \\ 1. LL.B, LL.M, PhD in Commercial and Property Law (Consumers Protection Law) (Nig.), B.L., ChMC; \\ Senior Lecturer, Department of Public Law, Faculty of Law, University of Uyo, Uyo, Nigeria. \\ 2. LL.B, B.L., ChMC; Postgraduate Student, Faculty of Law, University of Uyo, Uyo; Assistant Director, \\ Ministry of Justice, Akwa Ibom State, Nigeria.
}

\begin{abstract}
This work analyses the new structure of the National Industrial Court in Nigeria under the Constitution of the Federal Republic of Nigeria (Third Alteration) Act, 2010 as regards the finality of the Court's decisions on civil matters and causes. The work points out some legal problems created by the interpretation of the provisions of the Constitution particularly section 243 and argued that the said section has not removed the right of appeal to the Court of Appeal on other civil matters and causes. This work relies on some Nigerian Judicial opinions and those of some writers, and advocates that the Courts should adopt a purposeful and liberal interpretation of the Constitution that will meet the course of justice.
\end{abstract}

Key word: Jurisdiction, National Industrial Court of Nigeria, civil matter, appeal, Industrial Disputes, Labour.

\section{Introduction}

Labour matters play a vital role in the development and growth of any Country. Thus, no matter how well endowed a country might be in terms of natural resources, its wealth will not be properly harnessed if there is no proper organised labour system. In other words, the economic development of any country is dependent on the proper operation of the country's labour force.

In Nigeria, a major part of the organised labour system is the existence of a proper and effective dispute resolution mechanism for it is not possible that there will be no dispute between employees and employers in a workplace. Thus, no matter the measures taken by parties to avoid disputes or conflict in work places, there will always be dispute. This is so because conflicts are inevitable in any human relationship but the ability to resolve the dispute and conflict amicably and expeditiously under the law is one of the distinguishing factors between a civilize and primitive society.

It is in the effort to put up such dispute resolution mechanism that resulted in the enactment of Trade Dispute Act of 1976, which established the National Industrial Court. So many controversies surrounded the establishment of the Court that it resulted in the establishment of a specialized Court in 2006 with the enactment of National Industrial Court Act, which tried to make the Court a superior court of record by virtue of section 1(3)(a) of the said Act. The National Industrial Court was not accepted as a superior Court of record by virtue of the said Act and the Supreme Court of Nigeria later held that the said section 1(3) of the National Industrial Court Act was a violation of section 6(4)(a) and section 6(5) of the 1999 Constitution $^{1}$ and as such the National Industrial Court could not claim any exclusive jurisdiction on any matter to the exclusion of other superior Courts of record.

The situation led to the apparent confusion as to which Court had jurisdiction over industrial dispute. This resulted in the amendment of the 1999 Constitution through the Third Alteration Act, 2010. By the amendment, the issue of the legality and constitutionality of the National Industrial Court both as a superior Court of record as well as a Court with equivalent powers of a High Court was laid to rest. However, many writers and labour law practitioners are still not satisfy with the amendment regarding the jurisdiction of the said Court. It has been argued that the decision of the Court, except where contrary provisions are made is not subject to review by a higher judicial authority and that the purport of the amendment has technically made the Court a Court of first and last resort in virtually all its sphere of authority. ${ }^{2}$

This work is therefore to examine the scope of the jurisdiction of the National Industrial Court of Nigeria within the Constitution of the Federal Republic of Nigeria, 1999 (amended by $3^{\text {rd }}$ Alteration Act No. 3

\footnotetext{
${ }^{1}$ National Union of Electricity Employees v Bureau of Public Enterprises (2010)7 NWLR Pt 1194, p. 538.

2 S. Fagbemi, "Jurisdiction of the National Industrial Court of Nigeria: A Critical Analysis (2014) vol. 28 JLPG; Available online on http://iiste.org/Journals/index.php/JLPG/article/viewFile/14988/15226
} 
of 2010) as a Court of first and last resort in civil matters and causes. This paper will further consider the various reactions of the Court of Appeal to this issue and its jurisdiction over Appeals from National Industrial Court.

\section{Significance of the Research}

There has been conflicting decisions of the Courts regarding the right of appeal in civil causes and matters from National Industrial Court to the Court of Appeal. The significance of this work therefore is to analyse the jurisdictional scope of the National Industrial Court of Nigeria as it affects the finality of the decisions of the Courts. The work principally focuses on the interpretation of section 243(2) (3) and (4) of the 1999 Constitution (as amended) by various Courts.

\section{Statement of Research Problem}

Notwithstanding the laudable innovations in the amended Constitution of the Federal Republic of Nigeria in respect of the jurisdictional scope of the National Industrial Court, these innovations have been fraught by the provisions in the Constitution relating to the right of appeal in all civil matters from the National Industrial Court to the Court of Appeal.

Section 243(2), (3) and (4) of the said Constitution has been interpreted by some Writers and Courts to deprive parties of their right of appeal which is not only a Constitutional right but an international recognised right which properly guarantees the right of an aggrieved party to proper judicial audience by way of an Appeal. This interpretation has caused many problems among litigants and even the Courts. It is such problems that necessitated this work.

\section{Clarification of Concepts}

Appeal has to do with a formal application to a higher court. ${ }^{3}$ The Supreme Court has held an appeal to be "... substantially a complaint against the decision of a trial Court. ${ }^{4}$ The purpose and essence of an appeal is to find out whether the Lower Court came to the right or correct decision in its resolution of the issues canvassed before it. The appeal therefore is a complaint against the resolution arrived at by the Lower Court." 5

The term, Jurisdiction, has been described as the lifeblood of any adjudication, the fiat, the stamp of authority to adjudicate. ${ }^{6}$ Jurisdiction is the authority, right or power, which a Court has to decide matters that are litigated before it or to take cognizance of matters, presented in a formal way for its decision. Statute, Charter or Commission imposes the limits of this authority under which, the Court is constituted and maybe extended or restricted by similar means. ${ }^{7}$ Jurisdiction is therefore, the extent to which a Court can exercise power or authority over a specific matter. The jurisdiction of Courts depends on the level that each Court is placed in the ranking of courts. The ranking here is always entrenched in the Constitution of a country. In Nigeria, the amended 1999 Constitution clearly states out the ranking of various Courts and their jurisdiction. By the said Constitution, a lower Court cannot adjudicate on matters that are constitutionally reserved for Courts of superior record. In order to appreciate the jurisdiction of the National Industrial Court of Nigeria as to whether it is a Court of first and last resort, it is pertinent to trace a brief history of the Court.

\section{The Evolution of the National Industrial Court of Nigeria}

The Trade Dispute (Arbitration and Inquiry) Act of 1941 first established the statutory machinery for the settlement of trade disputes. That Act gave powers to the Minister of Labour to intervene by means of conciliation, formal inquiry and arbitration where negotiation had broken down. The said Act had two major setbacks. The first, being that the parties were vested with the absolute discretion to decide whether or not they would avail themselves of the machinery provided. Although the Minister could appoint a conciliator on application of one of the parties, he needed the consent of both parties to set up an arbitration tribunal. The second problem was that there were no permanent institutions laid down before which the disputing parties could go for the settlement of their labour disputes. Instead, an ad hoc body, an arbitration panel had to be set up for a particular dispute and once it gave its decisions it became functus officio. ${ }^{8}$

\footnotetext{
${ }^{3}$ Marini Robinson and George Davidson (eds), Chambers 21 st Century Dictionary (1996) 59.

${ }^{4}$ Minister of Petroleum Resources v Expo Shipping Line (Nig) Ltd (2010) 1 NWLR (Pt. 1208) Pg 261 at 293.

${ }^{5}$ Olaosebikan $v$ Ajiboye \& Others (2016) LPELR-41214(CA) Amaechi v INEC (2008) LPELR (446) 1 at 46; and Obasi v Onwuka (1987) LPELR (2152) 1 at 10

${ }^{6}$ Lado v CPC (2011)18 NWLR Pt. 1279 Pg 689; Katto v CBN (1991) 9 NWLR Pt 213 Pg 126 @ 149.)

${ }^{7}$ J. B. Saunders, Mozley \& Whiteley's Law Dictionary $\left(9^{\text {th }}\right.$ edn. Butterworth, London 1977) p. 181.

${ }^{8}$ Babatunde Adejumo, "The Role of the Judiciary in Industrial Harmony." being commentary delivered at 2007 all Nigeria Judges' Conference organised by the National Judicial Institute on $5^{\text {th }}-9^{\text {th }}$ November, 2007. Available online at www.nicn.gov.ng/1php. Accessed on 4th April 2017; Akintunde Emiola, Nigeria Labour Law, (Publishing Limited, Ogbomoso, Nigeria, 2000 p. 358; and Oluwakayo O. Arowosegbe "National Industrial Court and the Quest for Industrial Harmony and Sustainable Economic Growth and Development in 
These setbacks in the Trade Dispute (Arbitration and Inquiry) Act of 1941 lasted till the enactment of the Trade Disputes (Emergency Provisions) Decree No. 21 of 1968 and the Trade Disputes (Emergency Provision) (Amendment No. 2) Decree No. 53 of 1969. The said Decrees were as a result of the prevailing circumstances being the period of the Nigerian Civil War. It was therefore expedient during the state of emergency to make transitional provisions for the settlement of trade disputes arising within the period. The said Decrees gave to the Minister of Labour compulsory power of intervention in trade disputes while retaining the usual methods of conciliation, formal inquiry and arbitration. The requirement for consent of the parties before the Minister could act was abrogated so that he could resort to these methods without the consent of the parties to the disputes. A time within with which a Minister could exercise his discretionary powers was provided in the said Decrees. The Decree of 1969 banned strikes and lock-outs under pain of imprisonment without option of fine and imposed stringent duties on the employer and employees to report strikes and lock-outs within 14 hours to the Inspector General of Police. It also established the Industrial Arbitration Tribunal for settlement of Industrial disputes.

Some of the problems in the Decrees persisted until 1976 when the Trade Disputes Decree No. 7 of 1976 was passed. The Decree, which later became the Trade Disputes Act, ${ }^{9}$ established the National Industrial Court. Section 20 of the said Act provided that:

There shall be a National Industrial Court for Nigeria (in this part of this Act referred to as "the Court") which shall have such jurisdiction and powers as are conferred on it by this or any other Act with respect to the settlement of trade disputes, the interpretation of collective agreements and matters connected therewith.

The Court was established to provide an avenue or forum for a smooth and flexible industrial dispute resolution regime which objective could not be met by the regular Courts. The Court started its adjudication functions in 1978 and its object was to provide for a stable and sustainable economy through quick, effective and efficient resolution of industrial disputes and protection of workers. ${ }^{10}$ The Court was conferred with jurisdiction and power with respect to settlement of trade disputes, the interpretation of collective agreements and matters connected therewith. ${ }^{11}$ It was the final arbiter in the hierarchy of the institutional mechanisms provided under the Trade Disputes Act for settlement of trade disputes. ${ }^{12}$

However, the roles ascribed to the court became fraught with controversies particularly so with its status, powers and jurisdiction in the hierarchy of courts under the Nigerian Legal system. ${ }^{13}$ Some of the controversies included the fact that the Court was not specifically listed in the Constitution. Moreover, the Court was the only Court of law in the country where litigants could not on their own volition, except when activating the interpretative jurisdiction of the court, approach the court to ventilate their grievances unless referred to the Court by the Minister of Labour. The referral and other discretionary powers of the Minister of Labour over matters relating to the Court meant that the influence of the Minister of Labour was overbearing.

Apart from the controversy caused by the overbearing influence of the Minister, the Court was regarded as an inferior Court whose decisions were subject to review by the High Court. The Supreme Court decision in the case of Western Steel Works v Iron and Steel Workers Union ${ }^{14}$ is particularly illustrative of judicial attitude towards the status of the National Industrial Court. In the case, the Supreme Court held that the National Industrial Court, being an inferior court, could not grant injunctive and declarative reliefs. What this position of the apex court translated into was that a superior court, such as a High Court could judicially review the decisions of the National Industrial Court.

Nigeria" (2011) Vol. 5 N0.4, Labour Law Review, 7 at p. 8, available at http://nicn.gov.ng/Archive/NATIONAL\%20INDUSTRIAL\%20COURT\%20AND\%20THE\%20QUEST\%20FO R\%20INDUSTRIAL\%20HARMONY\%20AND\%20SUSTAINABLE\%20ECONOMIC\%20GROWTH\%20AN D\%20DEVELOPMENT\%20IN\%20NIGERIA.pdf, accessed November 14, 2016.

${ }^{9}$ CAP T8 Laws of the Federation of Nigeria, 2004

${ }^{10}$ B. Aturu, "The National Industrial Court Under The 1999 Constitution and The Resolution of Industrial Disputes." The Nigerian Business Law and Practice Journal. Vol. 7, No. 1, 2012, pp 82-91.

11 Section 20(1) of the Trade Dispute Act, 2004.

12 This provision was first introduced into the Trade Dispute Act by Decree No 47 of 1992 . The position of the Decree as at that time could be understood since it was a military era when military decrees were deemed superior to the Constitution.

${ }^{13}$ O. D. "Ejere, Further Reflections on the Constitutionality of the National Industrial Court Act 2006" (2006) NJLIR, 1 59-74.

${ }^{14}$ (1987) 1, NWLR (Pt. 49) 284. 
In reaction to the attitude of the Supreme Court towards the National Industrial Court, the then Military Government of Nigeria promulgated the Trade Disputes (Amendment) Decree No. 47 of 1992. The Decree emphatically made the National Industrial Court a superior court of record. The Decree prohibited other regular courts from entertaining trade disputes, or inter or intra union disputes, and vested the exclusive jurisdiction to entertain same in the National Industrial Court. This position was easy to apply because of the supremacy of Decrees over other laws. Thus, the Supreme Court in $U d o h$ v $O H M B^{15}$ affirmed the exclusive jurisdiction of the NIC to hear and entertain trade disputes, and inter and intra -union disputes. The situation however changed in 1999 when the civilian took over power and the Decrees were no longer considered by the Courts as being supreme. $^{16}$

To solve the inadequacies that existed in the Trade Disputes Act and fill the gaps which had previously hindered the smooth working of the National Industrial Court and impeded it's attaining the primary objective of settlement of labour disputes, the National Industrial Court Act 2006 was enacted. One of the major effects of the National Industrial Court Act, 2006, was to take the Court out of the Trade Disputes Act and gave it a separate enabling law of its own. The Act was enacted to provide for the establishment of the National Industrial Court as a superior Court of record and confer jurisdiction on the court with respect to labour and industrial relations matters. ${ }^{17}$ The National Industrial Court Act expanded the original and appellate jurisdiction of the Court. The jurisdiction of the National Industrial Court in civil cases and matters is related to labour, trade unions, and industrial relations; environment and conditions of work, health, safety and welfare of labour; strike, lock-out or industrial action; and interpretation of collective agreements, award of arbitral tribunal, terms of settlement of labour dispute, et cetera ${ }^{18}$

Following the enactment of the National Industrial Court Act, the Court was regarded as a superior Court of record with its powers and jurisdiction clearly defined. Decisions of the National Industrial Court under the National Industrial Court Act, 2006 were final in respect of matters within its jurisdiction. According to Ogunye, ${ }^{19}$ This was not only understandable but also desirable in a trade dispute resolution system that was more arbitral and meant to promote good labour relations and industrial harmony than it was adversarial and adjudicatory. It was also noted that as at that time, many of the matters adjudicated by the court originated from conciliation and arbitration, under the Trade Dispute Act and that after the failure of such conciliation, a trade dispute was referred to the Industrial Arbitration Panel (IAP) by the Minister of Labour, and if the award of the Industrial Arbitration Panel was objected to by any of the trade disputants, the matter was further referred to the National Industrial Court for a final resolution. ${ }^{20}$

The National Industrial Court Act, 2006 tried to put to rest the raging controversies over the jurisdiction and status of the National Industrial Court. However, it also brought its share of the controversy. For instance, the Act was criticized for raising the status of the Court to that of a superior court of record and conferring on it exclusive jurisdiction on labour matters and trade disputes without a corresponding amendment to the Constitution of the Federal Republic of Nigeria. ${ }^{21}$

Amidst all the criticism, the Supreme Court finally led the issue to rest when in the case of National Union of Electricity Employees and Anor. v Bureau of Public Enterprise ${ }^{22}$ it held that the exclusive jurisdiction conferred on the National Industrial Court by the 2006 Act was unconstitutional and that the High Court of the

15 (1993) 7 NWLR (Pt. 304) 139

${ }^{16}$ Dokubo v Kalango (2003) 15 WRN 32; A.G. Oyo v NLC (2003) 8 NWLR 1. The only singular exception to the foregoing judicial authorities was the case of Ekong $v$ Oside (2004) All FWLR 562.

${ }^{17}$ See the long title of the said Act.

18 Dokubo v Kalango (2003) 15 WRN 32; A.G. Oyo v NLC (2003) 8 NWLR 1. The only singular exception to the foregoing judicial authorities was the case of Ekong $v$ Oside (2004) All FWLR 562; NIC Act 2006, s. 7.

19 J. Ogunye, National Industrial Court and Judicial Absolutism in Nigeria, Premium Times, (February 14, 2014) available online @ http://www.premiumtimesng.com/opinion/155180-national industrial-court-judicialabsolutism-nigeria-jiti-ogunye.html. Accessed on 4th April 2017.

${ }^{20}$ Ogunye, 2004 (supra); Sections 3(2), 5, 7, 8 and 13(2) of the Trade Dispute Act.

${ }^{21}$ Gbenga Ojo, "Legal Anatomy of the National Industrial Court Act 2006: The Need for Legislative ReThinking” (June, 2008) Labour Law Review, vol. 2, No. 2, pp. 1 -24; N. I. E Worugji, et al, "The NIC Act (2006) and the Jurisdictional Conflict in Adjudicatory Settlement of Labour Disputes in Nigeria: An Unresolved Issue." (April, 2007) Labour Law Review, vol. 1, No. 2, pp. 25 -42; A. B. Chiafor, "Reflections on the Constitutionality of the Superior Court of Record Status and Exclusive Jurisdiction Clauses of the NIC Act, 2006," (2007) Labour Law Review (NJLIR) vol. 1 No. 3; O. D. Ejere, "Further Reflections on the Constitutionality of the National Industrial Court Act, 2006" (2007) Labour Law Review (NJLIR) vol. 1 No. 4 , p. 59; O. D. Amucheazi \& E. A. Oji "The Status of the National Industrial Court under the 1999 Constitution" (2008) Labour Law Review (NJLIR) vol. 2 No. 3, p. 1.

22 (2010) 7 NWLR (Pt. 1194) 538. 
States and of the Federal Capital Territory had jurisdiction to entertain and hear labour matters. The Supreme Court further noted that without an amendment to the Constitution, the regular High Courts would continue to exercise jurisdiction on labour matters. Indeed, almost in a reaction to the decision of the Supreme Court decision, the Nigeria National Assembly in collaboration with the State House of Assemblies in Nigeria in 2010 amended the Nigeria Constitution through the Constitution of the Federal Republic of Nigeria (Third Alteration) Amendment Act, 2010 thus incorporating the establishment of the National Industrial Court, its composition and power like other superior courts of record into the provisions of the Constitution. ${ }^{23}$

\section{The National Industrial Court of Nigeria Under the Constitution of the Federal Republic of Nigeria (Third Alteration)}

Section 6 of the Third Alteration Act established The National Industrial Court of Nigeria by introducing new Section 254A - F. The Act, which came into effect on 4th March 2011 included National Industrial Court as a superior Court of Record. ${ }^{24}$ This clearly put to rest the previous controversies about the power and jurisdiction of the Court. ${ }^{25}$ The Act did not only confer a wide jurisdiction on the Court but also introduced and recognised the concept of unfair labour practices. The extent of the jurisdiction of the NICN is well spelt out in Section $254 \mathrm{C}$ of the Constitution wherein the Court is vested with exclusive jurisdiction in relation to matters enumerated therein. It ensured the application of international best practices, which include international conventions, treaties, and protocols that relate to labour issues, which are ratified by Nigeria. ${ }^{26}$

The National Industrial Court in exercise of its jurisdiction is also allowed to establish Alternative Dispute Resolution Centre within its premises. ${ }^{27}$ This innovation is believe to afford the disputing employer and employee the opportunity to have their disputes resolved in an informal forum void of legal technicalities that encumber any formal Court setting. ${ }^{28}$ The NICN has been conferred with jurisdiction and powers in criminal causes and matters arising from any cause or matter of which jurisdiction is conferred on the National Industrial Court. ${ }^{29}$ In exercising this criminal jurisdiction, the Court is empowered to apply the provisions of the Criminal Code, Penal Code, Criminal Procedure Act, Criminal Procedure Code and Evidence Act. ${ }^{30}$ For the purpose of exercising the jurisdiction conferred on it, the Court has been conferred with all the powers of a High Court. ${ }^{31}$

It is very obvious that the altered constitution has retained all the good conceptions associated with the National Industrial Court Act of 2006 while it also tries to avoid the defects associated with it. One of such defect is the lifting up of section 9 of the NIC Act 2006 and inserting it in the Constitution as Section 243(2) and (3). This has now brought us to the nitty-gritty of this work.

\section{Appeals from National Industrial Court of Nigeria}

\section{Under the Constitution of the Federal Republic of Nigeria, 1999 (Third Alteration)}

As can be seen from the listed items under Section 254C of the Constitution, the National Industrial Court has now been developed from being a Court of resolution of trade, labour or industrial dispute to a Court that has jurisdiction to entertain anything labour, child labour, child abuse, human trafficking and sexual harassment at the workplace. Despite this laudable development, the Constitution of the Federal Republic of Nigeria 1999 (Third Alteration) has some shortcomings. One of which is an attempt to vest the National Industrial Court with the jurisdiction of a Court of first and last resort.

Under the Constitution (Third Alteration), the right of Appeal from the National Industrial Court of Nigeria depends on the nature of the suit. In other words, the right of Appeal depends on whether the cause is civil or criminal. In criminal causes and matters, the Appeal lies from the decision of the National Industrial

23 B. B. Kanyip, "The Jurisdiction of the National Industrial Court in the Light of the Third Alteration to the 1999 Constitution of the Federal Republic of Nigeria", being a Lecture presented at the Lagos State Ministry of Justice in-House Training Programme tagged. Legal Education and Research Node (LEARN) on 1stMarch 2012, p. 18.

${ }^{24}$ Constitution of the Federal Republic of Nigeria (Third Alteration) Act, 2010.

${ }^{25}$ C. K. Agomo, Nigerian Employment and Labour Relations Law and Practice ( $1^{\text {st }}$ ed. Concept Publication Limited. Lagos 2011) p.339.

${ }^{26}$ Section 254C (2) of the Constitution of Federal Republic of Nigeria.

${ }^{27}$ Ibid.

${ }^{28}$ F. A. Philip, 'National Industrial Court and the Third Alteration Act: The Emerging Trend' U. Udok and I.

Essien (eds), Essays in Honour of Prof. Enefiok Essien (Department of Private Law, Faculty of Law, Uyo 2016) p. 229.

29 Section 254(5) of Constitution of the Federal Republic of Nigeria.

${ }^{30}$ Section $254 \mathrm{~F}(2)$ supra.

31 (254D(1) supra. 
Court to the Court of Appeal as of right. ${ }^{32}$ An Appeal shall lie even up to Supreme Court in respect to causes and matters within the criminal jurisdiction of the National Industrial Court. ${ }^{33}$

The situation is not that simple in civil causes and matters. Many writers ${ }^{34}$ are of the opinion that in civil causes and matters, an aggrieved party's right of appeal from National Industrial Court to Court of Appeal are limited to issues bothering on fundamental rights. Their opinion is based on the provisions of sections 9 (1) of the NIC Act 2006, Section 243 (2) and (3) of the Constitution, which provides thus:

Section 9(1)

Subject to the provisions of the Constitution of the Federal Republic of Nigeria, 1999, and subsection (2) of this Section, no appeal shall lie from the decisions of the court to the Court of Appeal or any other court except as may be prescribed by this Act or any other Act of the National Assembly.

(2) An appeal from the decision of the Court shall lie only as of right to the Court of Appeal on questions of fundamental rights as contained in Chapter IV of the Constitution of the Federal Republic of Nigeria."

Section 243(2), (3) and (4)

(2). An Appeal shall lie from the decision of the National Industrial Court as of right to the Court of Appeal on questions of fundamental rights as contained in Chapter IV of this Constitution as it relates to matters upon which the National Industrial Court has jurisdiction.

(3) An Appeal shall only lie from the decision of the National Industrial Court to the Court of Appeal as may be prescribed by an Act of the National Assembly:

Provided that where an Act or Law prescribes that an appeal shall lie from the decisions of the National Industrial Court to the Court of Appeal, such Appeal shall be with the leave of the Court of Appeal.

(4) Without prejudice to the provisions of Section 254C (5) of this Act, the decision of the Court of Appeal in respect of any Appeal arising from any civil jurisdiction of the National Industrial Court shall be final..

According to them, while appeal from the decision of the Federal High Court and a High Court lie to the Court of Appeal as of right, an appeal from the decision of the National Industrial Court as of right is limited to questions of fundamental right as contained in Chapter IV of the Constitution. In all other decisions, an aggrieved litigant can only appeal against the decision of National Industrial Court only at the mercy of the National Assembly or at best appeal with the leave of the Court of Appeal where the enabling Act or Law prescribes an appeal. $^{35}$

In practice, the Courts of Appeal are actually divided in opinion as to whether any decision of the National Industrial Court is subject to Appeal in civil causes and matters. In five Appeal cases before the Ekiti Judicial Division of the Court of Appeal, the Court was faced with such a question relating to the right of appeal from the National Industrial Court of Nigeria in five Appeals before it. The Court in the said Appeals - Local Government Service Commission, Ekiti Olamiju; ${ }^{36}$ Local Government Service Commission, Ekiti v Asubiojo ${ }^{37}$ Local Government Service Commission, Ekiti v Jegede ${ }^{38}$ Local Government Service Commission, Ekiti v. Ajayi, ${ }^{39}$ Local Government Service Commission, Ekiti v Bamisaye ${ }^{40}$ was consistent in granting leave to the

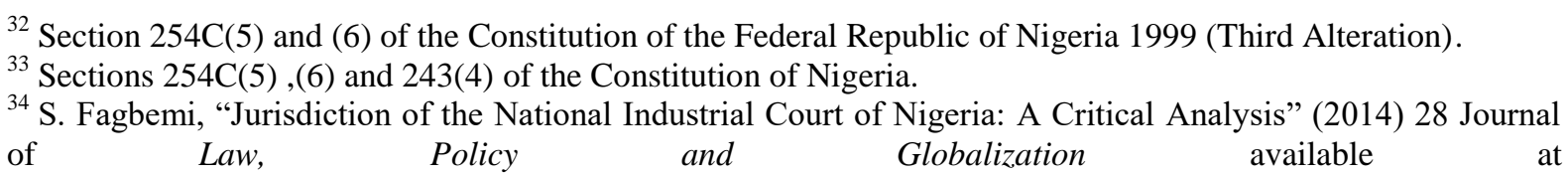
$\begin{array}{ccccc}\text { of Law, Policy } & \text { and } & \text { Globalization } & \text { available } & \text { at } \\ \text { http://www.isteng/journals/index/php/JLPG/article/viewfile/14988/15226, accessed on April 4, 2017; E. E. }\end{array}$ Ekanem, and E. V. Daniel, "A Critique of the Legal Framework for the National Industrial Court of Nigeria and its Impact on the Nigerian Worker" (2017) 58 Journal of Law, Policy and Globalization available at http://iiste.org/Journals/index.php/JLPG/article/viewFile/35567/36587, accessed on April 4, 2017).

35 S. Fagbemi, op cit; and Ekanem, and Daniel, op cit.

${ }^{36} \mathrm{CA} / \mathrm{EK} / 69 / \mathrm{M} / 2012$ reported in (2013)LPELR - 20409 (CA).

${ }^{37} \mathrm{CA} / \mathrm{EK} / 72 / \mathrm{M} / 2012$ reported in (2013)LPELR - 20403 (CA).

${ }^{38} \mathrm{CA} / \mathrm{EK} / 07 / \mathrm{M} / 2012$ reported in (2013)LPELR - 21131 (CA).

${ }^{39} \mathrm{CA} / \mathrm{EK} / 70 / \mathrm{M} / 2012$ reported in (2013)LPELR - 21133 (CA).

${ }^{40} \mathrm{CA} / \mathrm{EK} / 69 / \mathrm{M} / 2012$ reported in (2013)LPELR - 20407 (CA).

DOI: 10.9790/0837-2204075868 www.iosrjournals.org 63 | Page 
Appellants/Applicants to appeal against the decision of the National Industrial Court of Nigeria notwithstanding the fact that the questions that arose did not relate to issue of fundamental right. The reasoning by the Court of Appeal, Ekiti Judicial Division in the above cases is really very compelling and more reasonable.

In Coca-Cola (Nig.) Ltd. v Akinsanya, ${ }^{41}$ an opportunity was further presented to the Court of Appeal to make a pronouncement on the right of appeal from National Industrial Court. In that case, the Appellant filed a Motion on Notice praying for an order of the lower court for a case stated to the Court of Appeal for the determination of the constitutional question as to whether the jurisdiction of the National Industrial Court as contained in Section $254 \mathrm{C}(1)$ of the Constitution extends to all cases of private individual contractual employment or is limited to industrial relations and only to employment matters arising from or connected with trade disputes, collective agreements, labour and industrial relations. Instead of referring the question to the Court of Appeal, the trial court delivered a Ruling and held that it had jurisdiction over the claims of the (Respondent) on the authority of Section 7 of NICA, 2006 and Section 254C (1) of the Constitution, as amended' and that 'the question posed by the Appellants does not raise any substantial issue of law to warrant referring the case. Upon appeal by the Appellant, the Respondent filed a notice of preliminary objection challenging the competence of the appeal, on the ground, inter alia, that the Court of Appeal lacks jurisdiction to entertain the appeal having regard to the fact that the appellate jurisdiction of the Court of Appeal as provided under the 1999 Constitution over decisions of the National Industrial Court only applies to Fundamental Human Rights Enforcement actions, criminal matters as well as in cases where the National Assembly has conferred additional appellate jurisdiction on the Court of Appeal. The court unanimously overruled the Respondents' objection under different reasons. They however agreed that the question submitted by the Appellant to the lower Court for reference to the Court of Appeal for determination patently raised a substantial question of law as it bothers on jurisdiction of the Court. Saulawa JCA however made a very interesting observation to the effect that the Court of Appeal has a duty to resolve the inconsistency inherent in the provisions of the Constitution with regard to the right of appeal from the National Industrial Court to the Court of Appeal and that it would amount to absurdity and a negation to the fundamental doctrines of interpretation if the provision of Section 243(2) and (3) of the Constitution are not construed in conjunction with the well set out provisions of sections 240, 241 and 242 of the said Constitution.

The Court of Appeal, Lagos Division did not follow the views expressed by the Ekiti State Division but rather held in Lagos Sheraton Hotel and Towers v. Hotel and Personal Services Senior Staff Association ${ }^{42}$ that the National Industrial Court of Nigeria is the final Court in civil labour matters. In that case, the Respondent, a trade Association had sued the Appellant and obtained relief from the National Industrial Court of Nigeria sitting in Lagos, against the Appellant on behalf of members of the Association whose employment had been terminated. The hotel filed an appeal to the Lagos Division of the Court of Appeal for leave to appeal against the decision, but the Court unanimously dismissed the application for leave and held per Oseji JCA that the Constitution only recognises right of appeal in criminal matters and in questions of fundamental rights and that an Appeal on other matters is subject to an Act of the National Assembly. The Court further stated that, since such an Act does not exist, the decision of the National Industrial Court is final on the issue.

The uncertainty continued with different Courts of Appeal stating divergence views on this issue. In the case of Federal Ministry of Health v. Trade Union Members of the Joint Health Sectors Union (JOHESU) \& $\mathrm{Ors}^{43}$ where the Abuja Division of the Court of Appeal was called upon to determine the question as to whether by the combined effect of Section 243(3) of the Constitution 1999 (as amended) and Section 9 of the National Industrial Court Act, 2006, the Court of Appeal can exercise appellate jurisdiction over the decision of the National Industrial Court in civil matter not predicated on fundamental rights. The Court did not hesitate in holding that it is vested with the appellate jurisdiction to determine Appeal from the National Industrial Court in all civil matters. Tur, J.C.A ${ }^{44}$ succinctly captured the reasoning of the Court in reaching this decision in a beautiful display of legal erudition thus:

My humble view is that in the course of the National Industrial Court exercising jurisdiction, a question of the fundamental rights of a party under Chapter IV of the Constitution may arise which may necessitate the party aggrieved to appeal to the Court of Appeal. Where such a circumstance has arisen, an appeal shall lie from the National Industrial

\footnotetext{
41 (2013) 18 NWLR (Pt.1386) 255.

42 2014 LPELR-23340 (CA)

43 (2014) LPELR - 23546 (CA) (Interestingly, the cases of Coca-Cola v Akinsaya, Lagos State (supra), and Sheraton Hotel \& Towers $v$ Hotel and Personal Services Senior Staff Association (supra) were all relied upon by parties.

44 At pp. 33-34, paras, F-C 
Court as of right to the Court of Appeal. But in all other situations or circumstances the aggrieved party has to obtain leave to appeal to the Court of Appeal else the appeal shall be rendered incompetent. Indeed, that was the situation in Coca Cola Nig. Ltd \& Anor vs Akinsanya (supra) heavily relied upon by the learned Counsel to the respondents. Section 243(2) of the Constitution of the Federal Republic of Nigeria, 1999 Act No. 3 of 2010 is not intended to preclude a party aggrieved by the decision of the National Industrial Court from applying for leave to appeal to the Court of Appeal.

The implication here is that by the combine effect of sub-sections 243(2) (3) and (4) of the Constitution, an appeal shall lie as of right to the Court of Appeal from National Industrial Court in a matter of fundamental human right that arose as a result of the National Industrial Court exercising its exclusive jurisdiction in section 254C and for any other situation, an appeal shall lie to the Court of Appeal with leave.

The interpretation of section 243(2) and (3) by the Court of Appeal in the Federal Ministry of Health case, is quite elucidating. It is however disheartening that the Court of Appeal in subsequent decisions did not follow this reasoning thereby causing serious uncertainty in this area of Law. However, there is still hope that the Supreme Court will step in to clear this legal conundrum and resolve this vital constitutional question.

\section{The Civil Jurisdiction of the Court as a Court of First and Last Resort}

On a cursory look at section 9(1) of the National Industrial Court Act, 2006 and section 243(2) and (3) of the Constitution, one might indeed be tempted to hold that the sections make the National Industrial Court of Nigeria a Court of first and last resort in civil matters, except matters involving a breach of fundamental human rights or matters that will be prescribed by an Act of the National Assembly. This will amount to a narrow interpretation of the constitution that will certainly lead to absurdity. It is a trite principle of of law that in interpretation of a constitution, the entire provisions of the constitution should be construed together and not disjointedly so as to implement and not defeat the real intention of the legislators. ${ }^{45}$ In this vein, the provisions of sections 243(2) and (3) of the Constitution should be read and construed in conjunction with the provisions of sections 240, 241, 242, 243(4) of the Constitution.

The effect of the provisions of section 240 of the Constitution, which appears clear and unambiguous, can be understood to mean that the Court of Appeal shall have jurisdiction to the exclusion of any other Court of law in Nigeria to hear and determine appeals from the National Industrial Court, amongst other courts. The said section did not limit the type of appeals to be heard from NICN. If the intention of the legislators was to limit the type of appeals to be heard by the Court of Appeal, it would appear that the legislators would have expressly have stated so. In the absence of such expression in the Constitution, it can be contended that the proper interpretation would be that the Court of Appeal is vested with the appellate jurisdiction to hear appeals from the National NICN. This reasoning seems to be further emphasised by the provisions of section 243(4) of the Constitution, which states clearly, "the decision of the Court of Appeal in respect of any appeal arising from any civil jurisdiction of the National Industrial Court shall be final." The phrase "any appeal arising from any civil jurisdiction as used in section 243(4) presupposed that the appellate jurisdiction of the Court of Appeal was not in any way limited to matters of fundamental human rights. Any aggrieved person has a right of Appeal under this section to appeal to the Court of Appeal on any civil matter. If the Legislators had intended to limit such right of Appeal, it would clearly have stated so with a proviso. Any interpretation contrary to this would produce an unconstitutional result. Indeed, this was the view of Onyemenam JCA in the case of Local Government Service Commission, Ekiti v Bamisaye ${ }^{46}$ when he categorically stated thus:

The construction of the provisions of the constitution and constitutional powers must therefore not be used to attain unconstitutional result. A court of law must always ensure that whatever interpretation it gives to the provision of the constitution shall not yield or produce fruit that is anti-constitution. It will defeat the ends of constitution and achieve unconstitutional result to interpret section 243(2) and (3) to deny a citizen his right of appeal. Accordingly, to avoid harvesting unconstitutional

\footnotetext{
${ }^{45}$ Adesanya v Federal Republic of Nigeria (1981)5 SC 112; Okman Ojokoloso v Alamu (1987)7 SC (Part one) 124; FBN Plc v Akparabong Community Bank Ltd. (2006) 1 NWLR (Pt.962) 438 at 447; and P. P. A. v Saraki (2007) NWLR (Pt. 1064) 453/511 - 512

${ }^{46} \mathrm{CA} / \mathrm{EK} / 69 / \mathrm{M} / 2012$ reported in (2013)LPELR - 20409 (CA). 
result or defeating the ends of the constitution, since section 243 (3) seeks to oust the jurisdiction of this court; section 243(3) of the constitution must not only be read and interpreted together with other sections of the constitution but strictly interpreted.

The position here therefore is not to interpret the constitution so as to produce unconstitutional result. Interpreting section 243 of the Constitution as a whole to oust the jurisdiction of the Court of Appeal to hear any civil appeal from National Industrial Court will certainly produce an unconstitutional result.

It should also be noted that there seems to be no provisions in either the Constitution or the National Industrial Court Act that expressly bars the Court of Appeal from having jurisdiction to entertain appeal on civil matters from the NICN, furthermore, there also seems to be no provision that expressly prohibits a party from filing such appeal. Thus, the courts have appeared to be very consistent in holding that if an appellate court, like the Court of Appeal, is to be divested of its jurisdiction, it must be done by express provision and not by implication and that a court of law can only be made a final court by express provision and not by implication ${ }^{47}$ just as Section 243(4) of the Constitution has made the Court of Appeal a final Court on any decision in respect of any civil matter from the National Industrial Court. This is also the position in Section 246(3) of the Constitution where the Court of Appeal is made the final Court in respect of appeals arising from the National and State Houses of Assembly election petitions.

The absurdity in interpreting Section 243(2) and (3) of the constitution so as to vest the National Industrial Court with the draconian power of a Court of first and final resort can be hypothetical stated thus; if an employee is unlawfully sacked from work without her employers doing anything despite her complaint, she then approaches the the National Industrial Court for redress. If the said Court presided by a single Judge thinks otherwise and dismisses the case in favour of her employers, the employee will have no other recourse than to go back home to lick her wounds except she is able to allege a breach of her fundamental right under Chapter IV of the Constitution which is almost impossible because of the attitude of the Court in this regard. This can certainly not have been the intention of the Legislatures when they gave such expanded jurisdiction under section 254C to the National Industrial Court. Tur, J.C.A, in Federal Ministry of Health $v$ Trade Union Members of the Joint Health Sectors Union (JOHESU) \& Ors, ${ }^{48}$ captured this position aptly, when he stated thus:

I have set out the expansive jurisdiction of the National Industrial Court, particularly the subject matters upon which the Court may adjudicate not only in civil but criminal proceedings. Can it be sensibly argued that the National Assembly intended that no appeal shall lie from the decision of the National Industrial Court to the Court of Appeal except in cases involving fundamental rights under Chapter IV of the Constitution of the Federal Republic of Nigeria, 1999 as amended? I do not think so. If the argument of the learned Counsel to the respondents is upheld it will follow that no party aggrieved by the decision of the National Industrial Court involving any civil or criminal cause or matter can be subject of appeal to the Court of Appeal. In that case the decisions of the National Industrial Court shall be final. That will be absurd.

Indeed, the intention of the Legislators could not have been to deprive a party of his right, as the right of Appeal from the decision of a Court or Tribunal is one of the constitutionally guaranteed rights in Nigeria. ${ }^{49}$ The right is also an international recognised right in judicial proceedings. Apart from the Supreme Court of Nigeria, there is no other court of first instance in Nigeria exercising its original jurisdiction under section 232 of the Constitution, which decisions are final and not appealable, not even a court martial or tribunals including election tribunals. ${ }^{50}$

\section{Conclusion and Recommendations}

The National Industrial Court of Nigeria has indeed gone through many stages of development and has surpassed many problems and confusions associated with its jurisdiction. The regime of the Constitution of the

\footnotetext{
${ }^{47}$ Local Government Service Commission, Ekiti v Jegede (supra).

${ }^{48}$ Supra.

${ }^{49}$ Section 240 of the Constitution of the Federal Republic of Nigeria 1999.

${ }^{50}$ Fagbemi, op cit.
} 
Federal Republic of Nigeria (Third Alteration) Act, 2010 is believed to have repositioned the court to meeting the challenges of the present day industrial relations with the settlement of the long controversies and uncertainties over the true status and powers of the Court. However, the narrow interpretation of the provisions of section 243(2) and (3) of the Constitution has raised a problems, which perhaps, were never envisaged by the legislators, that is, by construing the NICN as a court of first and last resort, and thereby attempting to deprive the Court of Appeal of its appellate jurisdiction.

Many writers and the Courts are unanimous in their opinion that it is wrong for the National Industrial Court to be vested with such authority. They have however suggested an amendment to the Constitution or the National Industrial Court Act, 2006. In as much as it is agreed that there is need for such amendment so as to remove any form of doubt or ambiguity, it is recommended here that it will be better for the Court of Appeal and Supreme Court to adopt a purposeful and liberal interpretation of the provisions of the Constitution so as to achieve the fundamental aim of justice.

\section{REFERENCES}

[1] B. Chiafor, "Reflections on the Constitutionality of the Superior Court of Record Status and Exclusive Jurisdiction Clauses of the NIC Act, 2006," in Labour Law Review (NJLIR) Vol. 1 No. 3 (2007).

[2] Akintunde Emiola, Nigeria Labour Law, (Publishing Ltd, Ogbomoso, Nigeria, 2000.

[3] Aturu, "The National Industrial Court Under The 1999 Constitution and The Resolution of Industrial Disputes." The Nigerian Business Law and Practice Journal. Vol. 7, No. 1, 2012, pgs. 82 -91.

[4] B. Kanyip, "The Jurisdiction of the National Industrial Court in the Light of the Third Alteration to the 1999 Constitution of the Federal Republic of Nigeria”. A Guest Lecture presented at the Lagos State Ministry of Justice in-House Training Programme tagged. Legal Education and Research Node (LEARN) on $1^{\text {st }}$ March 2012 pp18).

[5] Babatunde Adejumo, OFR: "The Role of the Judiciary in Industrial Harmony." being commentary delivered at 2007 all Nigeria Judges' Conference organised by the National Judicial Institute on $5^{\text {th }}-9^{\text {th }}$ November, 2007.

[6] K. Agomo, Nigerian Employment and Labour Relations Law and Practice $\left(1^{\text {st }}\right.$ ed. Concept Publication Limited. Lagos 2011).

[7] E. Ekanem, and E. V. Daniel, "A Critique of the Legal Framework for the National Industrial Court of Nigeria and its Impact on the Nigerian Worker" (2017) 58 Journal of Law, Policy and Globalization available at http://iiste.org/Journals/index.php/JLPG/article/viewFile/35567/36587.

[8] A. Philip, 'National Industrial Court and the Third Alteration Act: The Emerging Trend' U. Udok and I. Essien (eds), Essays in Honour of Prof. Enefiok Essien (Department of Private Law, Faculty of Law, Uyo 2016) p. 229.

[9] Gbenga Ojo, "Legal Anatomy of the National Industrial Court Act 2006: The Need for Legislative ReThinking.” In Labour Law Review, Vol. 2, No. 2, June, 2008, pgs. 1 -24.

[10] J. B. Saunders, Mozley \& Whiteley's Law Dictionary $\left(9^{\text {th }}\right.$ edn. Butterworth, London 1977).

[11] J. Ogunye, National Industrial Court and Judicial Absolutism in Nigeria, Premium Times, (February 14, 2014) Available online @ http://www.premiumtimesng.com/opinion/155180-national industrial-courtjudicial-absolutism-nigeria-jiti-ogunye.html. Accessed on 4th April 2017.

[12] Marini Robinson and George Davidson (eds), Chambers 21st Century Dictionary (1996).

[13] N. I. E Worugji, et al, "The NIC Act (2006) and the Jurisdictional Conflict in Adjudicatory Settlement of Labour Disputes in Nigeria: An Unresolved Issue.” In Labour Law Review, Vol. 1, No. 2, April, 2007, pgs. $25-42$.

[14] O. D. Amucheazi \& E. A. Oji "The Status of the National Industrial Court under the 1999 Constitution" in Labour Law Review (NJLIR) Vol. 2 No. 3 (2008) p. 1).

[15] O. D. Ejere, "Further Reflections on the Constitutionality of the National Industrial Court Act, 2006" in Labour Law Review (NJLIR) Vol. 1 No. 4 (2007) p. 59.

[16] Oluwakayo O. Arowosegbe "National Industrial Court and the Quest for Industrial Harmony and Sustainable Economic Growth and Development in Nigeria” (2011) Vol. 5 N0.4, Labour Law Review, 7.

[17] S. Fagbemi, "Jurisdiction of the National Industrial Court of Nigeria: A Critical Analysis (2014) vol 28 JLPG; Available online on http://iiste.org/Journals/index.php/JLPG/article/viewFile/14988/15226.

Dr. Etefia Ekwere Ekanem; Bachelor of Laws (LL.B) (Hons) Degree (1999), Master of Laws (LL.M) Degree (University of Uyo, Nigeria) (2008), PhD Degree in Commercial and Property Law (Consumers Protection Law) (University of Nigeria) (2013), Barrister-at-Law (B.L.) (Nigerian Law School) and Solicitor of the Supreme Court of Nigeria 2000), Chartered Mediator and Conciliator (ChMC) (2006); Senior Lecturer in the 
Department of Public Law, and Postgraduate Coordinator of the Faculty of Law, University of Uyo, Uyo, Nigeria; and the President, Consumer Rights and Products Safety Awareness Initiative; Interest area: Consumer Protection Law, Commercial and Property Law, and Law of Labour Relations.

Bassey Johnson Ekanem: Bachelor of Laws (LL.B) (Hons) Degree (University of Uyo, Nigeria) (1998), Barrister-at-Law (B.L.) (Nigerian Law School)and Solicitor of the Supreme Court of Nigeria 1999); Postgraduate Student, Faculty of Law, University of Uyo, Uyo; and Assistant Director, Ministry of Justice, Akwa Ibom State, Nigeria. 